\title{
Social Entrepreneurship: Doing Well by Doing Good
}

Ken Harrington (The Bayberry Group)

Dave Feldman (Livability Project)

Nicholas Vitalari (Elasticity Labs)

KEYWORDS: Management of Companies \& Enterprises, Sales, Marketing, Advertising, Entrepreneurship, Leadership.

Can a socially conscious company be true both to its mission and to its bottom line? If there's conflict, what gets priority? It's a difficult balancing act and missteps can cost customers, especially among today's socially conscious Millennials. In this roundtable discussion, Ken Harrington of The Bayberry Group, Dave Feldman of the Livability Project and Nicholas Vitalari of Elasticity Labs talk about the importance of authenticity, and how entrepreneurs can harness their business skills towards making a better world. 